\title{
Standardization of critical boron level in soil and leaves of coconut palms grown in a tropical Entisol
}

\author{
Jeena Mathew $^{1 *}$, V. Krishnakumar ${ }^{1}$, V.Srinivasan ${ }^{2}$, Ravi Bhat ${ }^{3}$, C.G.Narayanan- \\ Namboothiri ${ }^{1}$, A. Abdul Haris ${ }^{1}$
}

${ }^{I}$ ICAR-Central Plantation Crops Research Institute, Regional Station, Kayamkulam,Kerala, India.

${ }^{2}$ ICAR-Indian Institute of Spices Research, Calicut, Kerala, India. ${ }^{3}$ ICAR-Central Plantation Crops Research Institute,Kasaragod,Kerala,India.*Corresponding author: jeenu15@gmail.com

\begin{abstract}
An experiment was conducted to standardize the critical boron level in soil and leaf samples of coconut palms grown in a typical Entisol of the Onattukara region of Kerala, India. Graded levels of boron as borax were applied at 0, 6, 12, 18 and $24 \mathrm{~g}$ per palm per year in four split doses. The critical boron level in soil and leaves was standardized using the following methods: the Cate and Nelson graphical (CN) method, the Mistcherlich equation (ME), and the quadratic plateau response (QP) method. In the $\mathrm{CN}$ method, the critical level of boron in soil and leaves was $0.48 \mathrm{mg} \mathrm{kg}^{-1}$ and $11.5 \mathrm{mg} \mathrm{kg}^{-1}$, respectively. In the ME model, the critical boron level in soil and leaves was $0.46 \mathrm{mg} \mathrm{kg}^{-1}$ and $7.55 \mathrm{mg} \mathrm{kg}^{-1}$, respectively. In the QP response curve, the critical level of boron in soil was estimated to be $0.87 \mathrm{mg} \mathrm{kg}^{-1}$, and in the leaf, the critical level was found to be $13.27 \mathrm{mg}$ $\mathrm{kg}^{-1}$. Because the level estimated via the graphical method and by the Mistcherlich equation is similar with regard to the soil boron, $0.48 \mathrm{mg} \mathrm{kg}^{-1}$ can be considered as the critical boron level in soil. Regarding the critical boron level in the leaf, values estimated via the $\mathrm{CN}$ method and the QP response curve are in proximity, and, hence, the critical boron level in leaf is $13.27 \mathrm{mg} \mathrm{kg}^{-1}$. These results suggest the application of $160 \mathrm{~g}$ of borax in four split doses when the levels of boron in soil and leaves fall below the estimated critical values for better use efficiency.
\end{abstract}

Keywords: Boron, coconut, sandy soil, critical level 


\section{Introduction}

The coconut is a perennial plantation crop with a considerable time lag of 36 months from primordial initiation to the stage of harvestable nuts. Hence, systematic management strategies need to be adopted for optimizing crop productivity. Boron is an essential micronutrient for coconut production and has important roles in pollen germination, pollen tube development, nut setting, and the general growth of the palm (Kamalakshiamma and Anithakumari, 1999; Broschat, 2011). Plants contain boron both in water-soluble and insoluble form, and the amount of water-soluble boron fluctuates with the amount of boron supplied (Marsh, 1942). When plants absorb boron as boric acid, the soluble fraction of boron increases, whereas the insoluble boron does not. The appearance of boron deficiency coincides with the decrease of water-insoluble boron content, and deficiency of boron in a plant mischaracterizes its fruit at the chemical, nutritional and morphological levels. Tropical acidic sandy soils are more prone to boron deficiency because of factors, such as low soil fertility levels, removal of nutrients by several successive crops, and the increased use of fertilizers and acidity correctives. These factors contribute to decreases in the solubility of several soil minerals containing boron (Mattiello et al. 2009). Communar and Keren (2006) indicated that sandy soils, low in organic matter, which are exposed to heavy rains, drain much of the boron to deeper layers. In soils with heavy clay, boron may also be unavailable to plants due to strong adsorption to soil particles (Chaudhary and Shukla, 2004).

Boron deficiency in soils coupled with heavy crop demand results in symptoms such as un-split leaves, button shedding, nut cracking, splitting of the husk and shell, and barren bunches and nuts. These symptoms are rampant in coconut growing tracts of tropical regions (Kamalakshiamma et al.2005). Baranwal et al.
(1989) confirmed that crown choking syndrome in coconuts is associated with boron deficiency.

Boron is commonly lost in sandy soil via lixiviation or dissolution in its water soluble form. However, it has been shown that adequate supplies of suitable carriers can ensure the availability of boron to palms without it being lost in water soluble forms. Pinho et al. (2008) reported that coconut palms grown in sandy soil with $710 \mathrm{~g} \mathrm{~kg}^{-1}$ of sand and $31 \mathrm{~g} \mathrm{~kg}^{-1}$ of organic matter in the upper layer $(0-0.4 \mathrm{~m})$ can absorb boron with no lixiviation after supplying the soil with $60 \mathrm{~g}$ of boric acid per plant.

Leaf nutrient analysis can serve as an index to diagnose chronic boron deficiency (Mills and Jones, 1996). The importance of encompassing leaf nutrient status for evolving fertilizer recommendations in plantation crops was suggested by Fairhurst and Mutert (1999) and Prabowo et al. (2010). Critical nutrient range should be developed for specific soil types, because the amount of nutrients removed per palm varies with age, soil type, productive potential and type of management practice adopted. Margate et al. (1979) reported that, based on the appearance of toxicity symptoms in hybrid seedlings, 13-14 ppm is the critical range of boron in coconut seedlings. Fixing the critical boron level in soil as well as in the leaf tissues enables optimal application of boron to palms. This fix may prevent over-application, thereby benefiting farmers economically. Because coconut is a perennial crop, with yield expression based on inputs and interactions with various biotic and abiotic factors, standardization of specific nutrient concentration ranges can optimize crop productivity. The present experiment was conducted in an acidic sandy soil to fix the critical boron range in soil and coconut plants so that the supply of boron could be modified based on the crop requirement. 


\section{Material and Methods}

\subsection{Experimental site}

The field experiment was conducted on an experimental farm $\left(9^{\circ} 8^{\prime} \mathrm{N}\right.$ latitude and $76^{\circ} 30^{\prime} \mathrm{E}$ longitude) of ICAR-Central Plantation Crops Research Institute, Regional Station, Kayamkulam, from 2011-2015 with coconut palms 25-30 years of age. The tropical monsoon climate provides a mean rainfall of $244.8 \mathrm{~mm}$ from May to December. The relative humidity ranges from $75.0-90.0 \%$, and the dry season lasts from December to April and is characterized by high temperatures (Max $35^{\circ} \mathrm{C}$ ). The soil of the site belongs to Typic Oxy Aquic Quartzi Pasamment, and the initial fertility status of the experimental site is presented in Table 1 . The initial boron content in the soil was $0.21 \mathrm{mg} \mathrm{kg}^{-1}$, which is rated as low (Kerala State Planning Board, 2013).

Table 1. Initial soil parameters at the experiment site.

\begin{tabular}{lc}
\hline Parameters & Content \\
\hline $\mathrm{pH}$ & 5.2 \\
$\mathrm{EC}\left(\mathrm{dSm}^{-1}\right)$ & 0.05 \\
Organic carbon $(\%)$ & 0.421 \\
Available P $\left(\mathrm{mg} \mathrm{kg}^{-1}\right)$ & 28.5 \\
Available $\mathrm{K}\left(\mathrm{mg} \mathrm{kg}^{-1}\right)$ & 72.5 \\
Exchangeable $\mathrm{Ca}\left(\mathrm{mg} \mathrm{kg}^{-1}\right)$ & 212.2 \\
Exchangeable $\mathrm{Mg}\left(\mathrm{mg} \mathrm{kg}^{-1}\right)$ & 63.5 \\
$0.1 \mathrm{~N} \mathrm{HCl} \mathrm{extractable} \mathrm{Fe}\left(\mathrm{mg} \mathrm{kg}^{-1}\right)$ & 15.2 \\
$0.1 \mathrm{~N} \mathrm{HCl}$ extractable $\mathrm{Mn}\left(\mathrm{mg} \mathrm{kg}^{-1}\right)$ & 12.5 \\
$0.1 \mathrm{~N} \mathrm{HCl}$ extractable Cu $\left(\mathrm{mg} \mathrm{kg}^{-1}\right)$ & 0.45 \\
0.1N HCl extractable $\mathrm{Zn}\left(\mathrm{mg} \mathrm{kg}^{-1}\right)$ & 1.25 \\
Hot Water Soluble B $\left(\mathrm{mg} \mathrm{kg}^{-1}\right)$ & 0.21 \\
\hline
\end{tabular}

Coconut palms of the West Coast Tall variety with boron deficiency symptoms, such as (a) fasciation ie., unfurling of leaflets (b) inflorescence necrosis, (c) button shedding (d) hen and chicken disorder, (e) longitudinal splitting of the nuts, and (f) malformed copra, were selected for the study.

\subsection{Recommended dose of fertilisers}

The recommended dose of fertilizers (RDF, i.e., 500 g N; $300 \mathrm{~g} \mathrm{P}_{2} \mathrm{O}_{5} ; 1000 \mathrm{~g} \mathrm{~K}_{2} \mathrm{O}$ ) were applied in two equal split doses as 1/3 in June and 2/3 in September
(Coconut Cultivation Practices, 2007). Nitrogen, phosphorus and potassium were supplied as urea, mussoriephos and muriate of potash, and boron was applied separately as borax $(10 \% \mathrm{~B})$ in four equal split doses every year during March, June, September and December. Fertilizers were applied $1.5 \mathrm{~m}$ away from the trunk of the palm and were thoroughly mixed into the soil.

\subsection{Treatments}

The experiment was carried out using a factorial randomized block design with 2 factors: husk (2 levels) 
and boron (5 levels). Husk burial in palm basins has been reported to improve the physico-chemical properties of the soil, including its organic matter content (Liyanage et al. 1993). Since boron is a mobile nutrient in soils with heavy leaching loss, husk burial was chosen as a factor in the experiment. There were 10 treatments with 5 different doses of boron, each with and without coconut husk burial, and eight replications were carried out per treatment, for a total of 80 palms. At the beginning of the experiment, husks were buried as a single layer near 40 palms, $30 \mathrm{~cm}$ away from the trunk around the base of the palm.

The treatments are as follows: husk levels, H1: without husk burial, $\mathrm{H} 2$ : with husk burial and boron levels, $\mathrm{B}_{1}$ : Control ( $0 \mathrm{~g}$ boron $+\mathrm{RDF}), \mathrm{B}_{2}: 6 \mathrm{~g}$ boron per palm + RDF, $\mathrm{B}_{3}: 12 \mathrm{~g}$ boron per palm $+\mathrm{RDF}, \mathrm{B}_{4}: 18 \mathrm{~g}$ boron per palm $+\mathrm{RDF}, \mathrm{B}_{5}: 24 \mathrm{~g}$ boron per palm $+\mathrm{RDF}$. The design was a factorial randomized block design with eight replicates per treatment combination.

\subsection{Soil Sampling}

Soil samples were collected from the palm basin at a distance of $1.5 \mathrm{~m}$ from the trunk, at depths of 0-25 $\mathrm{cm}$ and $25-50 \mathrm{~cm}$. Soil samples were collected before the initiation of the experiment and annually after the application of treatments. Soil samples were air dried, sieved and stored for subsequent analysis of hot water soluble boron.

\subsection{Leaf Sampling}

Leaf samples were collected from the youngest fully opened leaf just below the spindle leaf at the initiation of the experiment. To study the effect of treatments on the leaf boron content, samples were collected annually after treatment applications. Three leaflets on either side were collected from the middle of the frond and after removing the midrib, the leaflets were washed in quartz double distilled water, dried in an oven at 70 ${ }^{\circ} \mathrm{C}$, powdered (Chew, 1982; Magat,1992) and stored for later evaluation.

\subsection{Estimation of boron}

Half a gram of the powdered leaf sample was kept in a silica crucible and ashed in a muffle furnace at 550 ${ }^{\circ} \mathrm{C}$ for 5 hours (Reuter and Robinson, 1986; Mills and Jones, 1996). The ashed sample was acidified with 1:1 $\mathrm{HCl}$ and kept in a water bath for 15 minutes, made up to $25 \mathrm{ml}$ with quartz double distilled water. From the extract, boron content was determined colorimetrically using Azomethine- $\mathrm{H}$ reagent, and the absorbance was read at $420 \mathrm{~nm}$ (Malekani and Cresser, 1998). Soil boron was extracted using hot water as proposed by Berger and Troug (1939), and estimated colorimetrically using Azomethine-H by reading the absorbance at $420 \mathrm{~nm}$ in a UV Visible Spectrophotometer (JASCOV 600).

\subsection{Estimation of critical boron levels in soil and leaf}

The critical boron level in soil and leaves was fixed by plotting the nut yield per palm against the boron level in soil and leaves with three different methods. The first is the graphical method $(\mathrm{CN})$ by the scatter diagram, which was verified statistically (Cate and Nelson, 1971). In the graphical method, horizontal and vertical lines of the graph were positioned to maximize the number of points in the first and third quadrants. Critical concentrations (x) for $90 \%$ nut yield were calculated using the Mistcherlich equation (ME) i.e., $\mathrm{x}$ $=\ln (0.1 / \gamma) / \alpha$, where $\alpha=\sum(2.303 / \mathrm{x}) \log 10(\mathrm{a} / \mathrm{a}-\mathrm{y})$, (a is maximum estimated yield and $\mathrm{y}$ is estimated yield at different values of $\mathrm{x}$ ) and $\gamma=$ (Maximum estimated yield - minimum estimated yield)/maximum estimated yield), as suggested by Ware et al. (1982) and Sharma 
(1991). Critical limits were also worked out from the quadratic plateau (QP) response, which estimates the level of a nutrient beyond the point where its addition no longer increases yield. It also estimates the maximum attainable yield with the level of applied boron dose. The plateau occurs when the quadratic curve reaches its maximum point (Bullock and Bullock, 1994).

\subsection{Statistical analysis}

Analysis of Variance (ANOVA) was conducted using SPSS Software Version 16 to find the effect of treatments on the leaf and soil boron content, as well as on nut yield. The treatment means were compared using least significant difference (LSD). Regression models, as specified by different methods, were developed for fixing the critical boron levels in soil and leaves.

\section{Results}

\subsection{Recovery of boron deficiency symptoms}

Among the different symptoms, palms with fasciation alone formed the highest category ( $45 \%$ ), followed by palms exhibiting fasciation and inflorescence necrosis (17.5\%) (Table 2). Fifteen percent of the palms showed fasciation, inflorescence necrosis and button shedding. With the application of different treatments of boron, $76.25 \%$ palms recovered from different kinds of boron deficiency symptoms.
In total, $83.3 \%$ of the palms showed recovery of fasciation symptoms, whereas $80 \%$ of the palms recovered from the combined symptoms of fasciation and button shedding. In the case of palms showing symptoms such as fasciation along with inflorescence necrosis, recovery was $71.43 \%$. There was $62.5 \%$ recovery from the symptoms with inflorescence necrosis alone. The highest percentage recovery was observed in the category of palms exhibiting fasciation alone, without the expression of associated symptoms such as inflorescence necrosis and button shedding.

\subsection{Boron level in soil}

Boron is a limiting micronutrient in the sandy soils of coconut production systems. The no boron treatment recorded an average boron content of $0.25 \mathrm{mg} \mathrm{kg}^{-1}$, and a steady significant increase up to $0.89 \mathrm{mg} \mathrm{kg}^{-1}$ with the application of $12 \mathrm{~g}$ boron was observed, and thereafter demonstrated a declining trend (Table 3). This might be due to the crop removal and, to a certain extent, loss of nutrients from the sandy soil with low exchange capacity. This finding implies that even by increasing the dose of boron in sandy soil to a level of $24 \mathrm{~g} \mathrm{palm}^{-1}$, the corresponding increment in soil boron content has not occurred and was not utilized by the palm. Addition of husk burial has significantly increased the soil availability of boron $\left(0.63 \mathrm{mg} \mathrm{kg}^{-1}\right)$ compared to no husk addition $\left(0.41 \mathrm{mg} \mathrm{kg}^{-1}\right)$.

Table 2. Remission of boron deficiency symptoms

\begin{tabular}{c|c|c|c} 
Symptoms & $\begin{array}{c}\text { Per cent of } \\
\text { total palms }\end{array}$ & $\begin{array}{c}\text { Recovered } \\
\text { Palms } \\
(\%)\end{array}$ & $\begin{array}{c}\text { No. of } \\
\text { recovered } \\
\text { palms }\end{array}$ \\
\hline Fasciation & 45 & 37.5 & 30 \\
\hline Inflorescence Necrosis & 10 & 6.25 & 5 \\
\hline $\begin{array}{c}\text { sciation + Inflorescence Necrosis } \\
\text { Fasciation +Button Shedding }\end{array}$ & 17.5 & 12.5 & 10 \\
\hline $\begin{array}{c}\text { sciation +Inflorescence necrosis } \\
\text { +Button Shedding }\end{array}$ & 12.5 & 10 & 8 \\
\hline
\end{tabular}


Table 3. Effect of treatments on the leaf B, soil B and nut yield of coconut

\begin{tabular}{|c|c|c|c|c|c|c|c|c|c|c|c|c|}
\hline \multirow{3}{*}{$\begin{array}{l}\text { B levels } \\
\text { (g/palm) }\end{array}$} & \multicolumn{3}{|c|}{ Leaf $\mathrm{B}\left(\mathrm{mg} \mathrm{kg}^{-1}\right)$} & \multicolumn{3}{|c|}{ Soil B $\left(\mathrm{mg} \mathrm{kg}^{-1}\right)$} & \multicolumn{6}{|c|}{ Nut Yield (nuts/palm per year) } \\
\hline & \multirow[t]{2}{*}{ H1 } & \multirow[t]{2}{*}{$\mathrm{H} 2$} & \multirow[t]{2}{*}{ Mean } & \multirow[t]{2}{*}{ H1 } & \multirow[t]{2}{*}{$\mathrm{H} 2$} & \multirow[t]{2}{*}{ Mean } & 2011 & 2015 & 2011 & 2015 & 2011 & 2015 \\
\hline & & & & & & & \multicolumn{2}{|c|}{ H1 } & \multicolumn{2}{|c|}{$\mathrm{H} 2$} & \multicolumn{2}{|c|}{ Mean } \\
\hline 0 & 9.14 & 9.98 & 9.56 & 0.13 & 0.36 & 0.25 & 26.58 & 26.25 & 26.58 & 43.50 & 25.85 & 34.88 \\
\hline 6 & 10.48 & 12.69 & 11.58 & 0.19 & 0.50 & 0.34 & 40.31 & 39.38 & 40.31 & 68.13 & 38.68 & 53.75 \\
\hline 12 & 11.25 & 12.44 & 11.84 & 0.73 & 1.04 & 0.89 & 35.68 & 53.38 & 35.68 & 90.00 & 31.01 & 71.69 \\
\hline 18 & 12.25 & 13.19 & 12.72 & 0.51 & 0.72 & 0.61 & 37.31 & 62.50 & 37.31 & 94.00 & 30.88 & 78.25 \\
\hline 24 & 12.81 & 13.19 & 13.00 & 0.51 & 0.52 & 0.51 & 41.50 & 52.31 & 41.50 & 81.00 & 31.31 & 66.66 \\
\hline Mean & 11.19 & 12.30 & & 0.41 & 0.63 & & 36.28 & 46.76 & 36.28 & 75.33 & & \\
\hline SE Mean & \multicolumn{3}{|c|}{0.78} & \multicolumn{3}{|c|}{0.05} & \multicolumn{6}{|c|}{2.32} \\
\hline $\begin{array}{l}\text { LSD } \\
(p=0.05)\end{array}$ & \multicolumn{3}{|c|}{$\begin{array}{l}\text { B levels: } 1.09 ; \\
\text { Husk: } 0.69 ; \\
\text { Interaction: } 1.55\end{array}$} & \multicolumn{3}{|c|}{$\begin{array}{l}\text { B levels: } 0.07 ; \\
\text { Husk: } 0.05 ; \\
\text { Interaction: } 0.1\end{array}$} & \multicolumn{6}{|c|}{ B levels: 3.27 ; Husk: 2.07 ; Interaction: 4.62} \\
\hline
\end{tabular}

(H1:Without Husk; H2:With Husk)

\subsection{Boron content in the leaf}

A steady and significant increase in the content of leaf boron was observed with the increased rate of applied boron. The highest average leaf content of boron up to $13 \mathrm{mg} \mathrm{kg}^{-1}$ was observed with the application of $24 \mathrm{~g}$ boron per palm compared to the control, where 9.56 $\mathrm{mg} \mathrm{kg}{ }^{-1}$ was recorded. Husk burial also increased the leaf boron concentration significantly, as evidenced by an average content of $12.30 \mathrm{mg} \mathrm{kg}^{-1}$ in the treatment, compared to the no husk treatment, where the average boron content was $11.20 \mathrm{mg} \mathrm{kg}^{-1}$ (Table 3).

\subsection{Critical boron level in leaf and soil}

As per the $\mathrm{CN}$ graphical model, the critical boron level in soil was $0.48 \mathrm{mg} \mathrm{kg}^{-1}$ (Figure1), whereas by the QP model, it was $0.87 \mathrm{mg} \mathrm{kg}^{-1}$. The critical level determined using the ME model was similar to that of the $\mathrm{CN}$ graphical estimation with $0.46 \mathrm{mg} \mathrm{kg}^{-1}$ for soil boron at $90 \%$ sufficiency level.

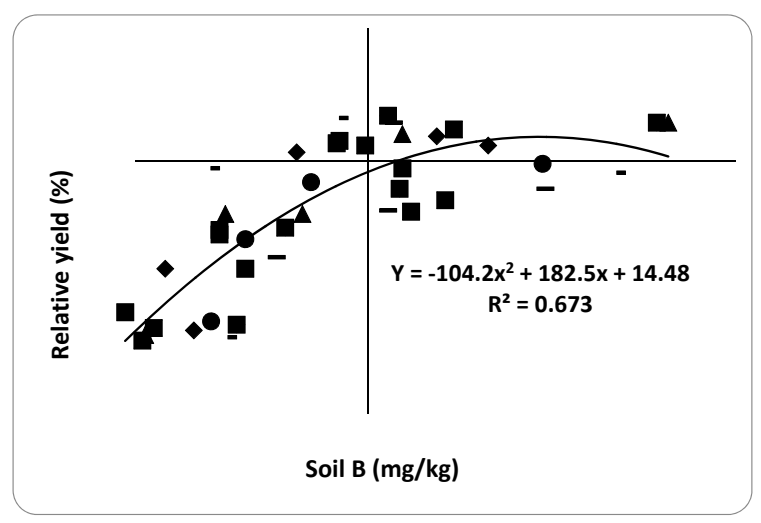

Figure 1. Scatter diagram and QP model for critical boron level in soil 
Leaf critical boron level was also estimated by $\mathrm{CN}$ graphical method with the value $11.5 \mathrm{mg} \mathrm{kg}^{-1}$ (Figure 2). In the QP response curve, the critical level was
$13.27 \mathrm{mg} \mathrm{kg}^{-1}$. At $90 \%$ sufficiency level, the critical boron level in leaves estimated through the ME model was $7.55 \mathrm{mg} \mathrm{kg}^{-1}$ (Table 4).

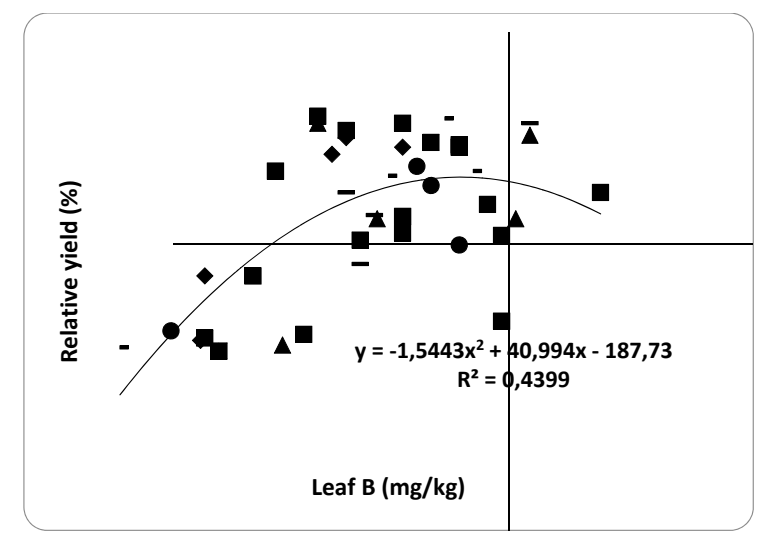

Figure 2. Scatter diagnram and QP model for critical boron level in coconut leaf.

Table 4. Critical levels as derived by different models

\begin{tabular}{|c|c|c|c|c|}
\hline \multirow[t]{2}{*}{ Statistical model } & \multirow[t]{2}{*}{ Model expression } & \multirow[t]{2}{*}{$\mathrm{R}^{2}$} & \multicolumn{2}{|c|}{$\begin{array}{c}\text { Critical } \\
\text { Concentration } \\
\left(\mathrm{mg} \mathrm{kg}^{-1}\right)\end{array}$} \\
\hline & & & Soil B & Leaf B \\
\hline $\begin{array}{l}\text { Cate and } \\
\text { Graphical }(\mathrm{CN})\end{array}$ & - & - & 0.48 & 11.50 \\
\hline \multirow{2}{*}{$\begin{array}{l}\text { Mitscherlich } \\
(\mathrm{ME})\end{array}$} & $\mathrm{Y}=94.3\left(1-0.664 \mathrm{e}^{-4.08 x}\right)$ & $0.988 * *$ & 0.46 & - \\
\hline & $\mathrm{Y}=84.3\left(1-0.509 \mathrm{e}^{-0.216 x}\right)$ & $0.998 * *$ & - & 7.55 \\
\hline \multirow[t]{2}{*}{ Quadratic Plateau (QP) } & $Y=182.5 x-104.2 x^{2}+14.48$ & $0.673^{* *}$ & 0.87 & - \\
\hline & $Y=40.99 x-1.544 x^{2}-187.7$ & $0.439 * *$ & - & 13.27 \\
\hline
\end{tabular}

\subsection{Nut yield as influenced by treatment application}

Nuts were harvested once every forty-five days from the experimental palms. Husk burial along with boron application showed a significant effect on the enhancement of nut yield, as indicated by the pre-experiment yield (Table 3). Improvements in yield over the pretreatment yield values were observed in all the boron treatments. While considering the effect of the application of boron on nut yield, we determined that the rate of increase in yield is not steady with the increased level of boron. The significantly highest yield of 78.25 nuts per palm compared to the control (34.88 nuts per palm) was recorded by the treatment that received $18 \mathrm{~g}$ boron per palm, followed by the treatment that received $12 \mathrm{~g}$ boron per palm with an average nut yield of 71.69 nuts.

\section{Discussion}

4.1. Relationship between levels of applied boron, leaf boron and yield

A steady and significant increase in leaf boron levels with an increase in applied boron levels was 
observed. Although there was an increase in the content of boron in leaf at the highest boron levels of 24 $\mathrm{g}$ per palm, it was not reflected in the nut yield. This might be due to the accumulation of boron in the leaf and its redistribution to the developing sinks, such as storage tissues, and not for nut production. Leaf boron content showed a significant positive correlation with soil boron content $\left(0.653^{*}\right)$ and a highly significant positive correlation with nut yield $\left(0.854^{* *}\right)$. The soil boron content also showed a highly significant positive correlation with nut yield $\left(0.810^{* *}\right)$.

Leaf boron content reached a maximum level of 13.19 $\mathrm{mg} \mathrm{kg}^{-1}$ with the application of $18 \mathrm{~g}$ boron, and further increases in the dose of boron did not show any corresponding increase in the leaf. The soil boron level showed a declining trend after the optimal dosage of $18 \mathrm{~g}$. This finding implies that even though surplus boron in the leaf as water soluble boron was present, any effect on the corresponding increase in yield was not reflected. The partitioning of the photosynthates to nut yield was efficient up to $18 \mathrm{~g}$ of boron per palm, and beyond this threshold, the palms may not be able to transform it into harvestable nuts. This result was considered for fixing the optimum dose of boron requirement for nut production.

Similar to this observation, in apple trees, a greater accumulation of boron in young leaves causing a reduction of boron movement to the fruitlets was observed by Wójcik and Mika (1998). In studies examining the relation between yield and leaf nutrient status in oil palm, Foster (2003) reported that increased availability of nutrients increased leaf nutrient content up to a certain level under given conditions, and beyond that level, the plant responds by increased growth with no change in nutrient levels.

In this experiment, it was determined that increased leaf boron content with an increase in the level of applied boron was not utilized for yield realization. With regard to the content of boron in soil, the increase in content was observed up to $180 \mathrm{~g}$, after which, a declining trend was observed. In sandy soils with low nutrient exchange capacity, increasing the boron application beyond an optimum dose may result in boron not being utilized by the plant for its metabolic activity. Hence, adoption of measures such as application of organic manure at $20 \mathrm{~kg} \mathrm{palm}^{-1}$, husk burial in the basin and split application can enhance the nutrient use efficiency. Moura et al.(2013) reported that the boron content in soil and leaves increased linearly with the incremental dose of borax, whereas nut production increased quadratically with the dose. The highest nut yield was recorded with boron at $2.1 \mathrm{~kg} \mathrm{ha}^{-1}$. At the highest dosage of $6 \mathrm{~kg} \mathrm{ha}^{-1}$ boron, production was reduced by $35 \%$. The positive influence of boron along with zinc on the enhancement of yield and productivity of maize by improving leaf chlorophyll and relative water content was reported by Wasaya et al.(2017).

\subsection{Standardisation of critical boron level in soil and leaf by different methods}

Nielsen (1966) emphasized the need to identify the critical plant part and stage of sampling for plant analysis results to be valid, as the nutrient concentration is dependent on several factors, such as part of the plant, growth stages of the crop, and time of day. According to Singh (2009), critical concentration is the lowest amount of nutrient in the plant accompanying the highest yield. A critical range of boron specifically to coconut growing soils has not been documented. The $\mathrm{CN}$ and ME models were worked out relating soil and leaf boron concentration with relative yield, whereas QP was worked out in relation with absolute yield parameters. There was a slight variation in critical limit values with the type of statistical model used. When the $\mathrm{CN}$ method yielded a level of $0.48 \mathrm{mg} \mathrm{kg}^{-1}$ for soil boron and $11.5 \mathrm{mg} \mathrm{kg}^{-1}$ for the leaf, boron content in soil and leaves at $90 \%$ of relative yield estimated by 
the ME method was $0.46 \mathrm{mg} \mathrm{kg}^{-1}$ and $7.55 \mathrm{mg} \mathrm{kg}$, respectively. The quadratic plateau model estimated the critical concentration in soil and leaf as $0.87 \mathrm{mg}$ $\mathrm{kg}^{-1}$ and $13.27 \mathrm{mg} \mathrm{kg}^{-1}$. The quadratic plateau has over-estimated the critical concentration with a slightly higher value than the other three methods.

Normally, critical ranges have been established for crops for which the probability of getting a response to fertilizer application varies. This finding implies that an optimum response to the added nutrient can be obtained if the level lies within the critical range specified. Fairhurst and Mutert (1999) stated that it is better to have an optimal range of concentration for any nutrient rather than an arbitrary value, such as the critical level or the optimal level. A general critical range of 20-25 mg boron $\mathrm{kg}^{-1}$ in plant tissue is specified for fruit trees, such as apples, peaches, apricots and pears (Ahmed et al. 2012). Moreover, 0.5 M $\mathrm{HCl}$-extractable-boron concentrations of $0.15 \mathrm{mg} \mathrm{kg}^{-1}$ in surface soil $(0-22.5 \mathrm{~cm})$ and $0.10 \mathrm{mg} \mathrm{kg}^{-1}$ in the subsoil $(22.5-45 \mathrm{~cm})$ were observed to be critical for citrus trees (Ahmed et al.2012).

Similarly, from the present study, a critical range of $7.50-13.27 \mathrm{mg} \mathrm{kg}^{-1}$ can be proposed for leaf boron concentration and $0.46-0.87 \mathrm{mg} \mathrm{kg}^{-1}$ for soil boron concentration for getting maximum response in coconut nut yield in sandy soils. Bhat and Sujatha (2014) developed the optimal levels of boron in arecanut, another plantation crop grown in the area, using a boundary line approach as $39.5 \mathrm{mg} \mathrm{kg}^{-1}$. It was reported by Prado (2008) that the interval between the leaf boron levels for maximum yield and that for toxicity is very narrow. The toxicity of boron caused chlorosis starting at the leaf tip and the margin of mature leaves in apple (Paparnakis et al., 2013). Hence, the boron sources should be carefully applied to coconut palms based on the critical level in soil and leaves.

\section{Conclusions}

In the acidic sandy soils of Kerala, for directing fertilizer applications for greater economic returns from coconut, the critical range of $7.50-13.27 \mathrm{mg} \mathrm{kg}^{-1}$ for leaf boron concentration and $0.46-0.83 \mathrm{mg} \mathrm{kg}^{-1}$ for soil boron concentration is proposed from these results. At the low end of the critical boron range, yield response is highly probable, and above this range, response will be less for the applied fertilizer. Based on the response function on applied nutrient doses for nut yield, $160 \mathrm{~g}$ of borax per palm (i.e., $16 \mathrm{~g}$ of boron per palm) is recommended as the optimal dose for soil application in coconut growing soils (Figure $3)$. The results of our study suggest that the boron sources need to be applied to coconut palms if the foliar and soil levels fall below the standardized critical levels. The optimal dose of $160 \mathrm{~g}$ of borax can be applied as four split doses along with husk burial to have enhanced boron use efficiency. 


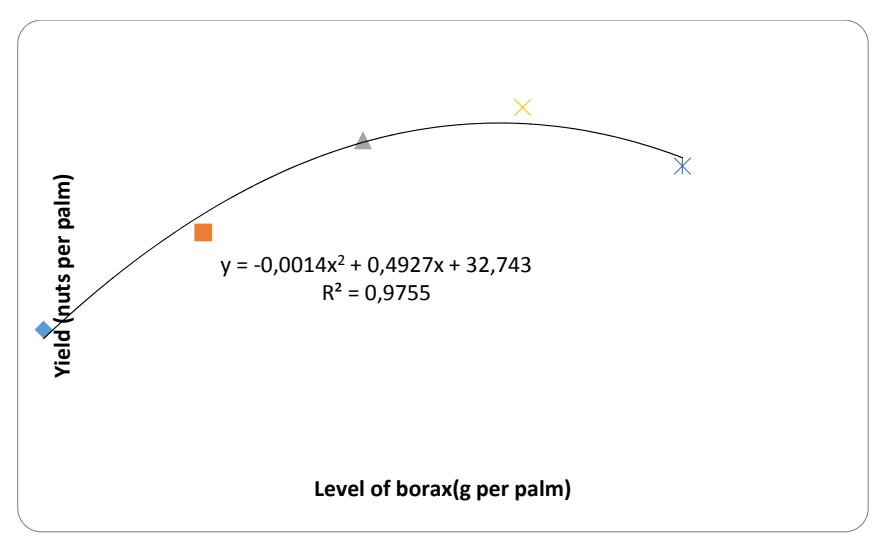

Figure 3. Response curve for fixing optimal boron dose

\section{References}

Baranwal, V.K., Manikantan, P., Ray, A.K. 1989. Crown choking disorder of coconut- A case study of boron deficiency. J. Plantation Crops. 17,114120.

Berger, KC., Truog, E. 1939. Boron deficiencies as revealed by plant and soil tests. J. Am. Soc. Agron. 32, 297-301.

Bhat, R., Sujatha, S. 2014. Establishing leaf nutrient norms for arecanut by boundary line approach. J. Plant Nutr. 36,849-862.

Broschat , K.T. 2011. Uptake and Distribution of Boron in Coconut and Paurotis Palms. Hortscience. 46, 1683-1686.

Bullock, G.D., Bullock, S.D. 1994. Quadratic and quadratic plus plateau model for predicting optimum nitrogen rate of corns. A comparison. Agron. J. 86,191-195.

Cate, R.B., Nelson, L.A. 1971. A Simple statistical procedure for partitioning soil test correlation data in two classes. Proc. Soil Sci. Soc. America. $35,658-660$.
Chaudhary, D.R., Shukla, L.M. 2004. Boron adsorption and desorption in arid soils of India. Agrochimica. 48, 141-152.

Chew, P.S. 1982. Nutrition of coconut-a review for formulating guidelines on fertiliser recommendation in Malaysia. Planter. 55, 141-155.

Coconut Cultivation Practices. 2007. Central Plantation Crops Research Institute, Kasargod, Kerala. Eds. (Dhanapal, R., Thampan, C). Extension Publication No. 179. p. 26.

Communar, G., Keren, R. 2006. Rate-limited boron transport in soils: the effect of soil texture and solution pH. Soil Sci. Soc. Am. J. 70, 882-892.

Fairhurst, T.H., Mutert, E. 1999. Interpretation and management of leaf analysis data. Better Crops. $13,48-51$.

Foster, H. 2003. Assessment of Oil Palm Fertilizer Requirements. In: Fairhurst, T.H. and Hardter, R., Eds, Oil Palm: Management for Large and Sustainable Yields, Potash and Phosphate Institute (PPI), Potash and Phosphate Institute of Canada (PPIC) and International Potash Institute, 231-257. 
Kamalakshiamma, P.G., Anithakumari, P. 1999. Boron deficiency in coconut. Symptoms and its management. Pamphlet. Indian Council of Agricultural Research - Central Plantation Crops Research Institute, Regional Station, Kayamkulam.

Kamalakshiamma, P.G., Shanavas, M., Prema, D., Mathew, J. 2005. Effect of borax application on coconut. CORD. 21, 74-82.|

Kerala State Planning Board. 2013. Soil fertility assessment and information management for enhancing crop productivity in Kerala. Kerala State Planning Board, Thiruvananthapuram, pp.1-514.

Liyanage, M.D., Jayasekara, K.S., Fernandopulle, M.N. 1993. Effects of application of coconut husk and coir dust on the yield of coconut. COCOS. 9, 15-22.

Magat, S.S. 1992. Coconut. In: IFA World Fertiliser Use Manual. International Fertiliser Industry Association, Paris, pp. 234-244.

Malekani, K., Cresser, M.S. 1998. Comparison of three methods for determining B in soils, Plants and water samples. Commun. Soil Sci. Plant Anal. 29, 285-304.

Margate, R.Z., Magat, S.S., Abad, R.G. 1979. Boron requirement of hybrid coconut seedlings grown in an inland coconut soil of Davo. Paper presented during the 10th Annual Scientific Meeting of the Crop Science Society of the Philippines, 23-25 April, UPLB,Coliege, Laguna.

Marsh, R.P. 1942. Comparitive study of the calciumboron metabolism of representative dicots and monocots. Soil Sci. 53, 75-76.

Mattiello, E.M., Ruiz, H.A.; Silva, I.R.; Barros, N.F., Neves, J.C.L., Behling, M. 2009. Transport of boron in the soil and its absorption by eucaliptus. J. of Soil Sci. 33, 1281-1290.
Mills, H.A., Jones, J.B. 1996. Plant Analysis Hand book II. MicroMacro Publishing, Athens, GA, USA.

Moura, J.Z., Prado, R.M., Benvido, R.N., Chaves, A.L. 2013. Applying boron to coconut palm plants: effects on plant nutritional status and on productivity boron to coconut palm trees. J. Soil Sci. Plant. Nutr. 13, 79-85

Nielsen, F. 1966. An approach towards interpreting and controlling the nutrient status of growing plants by chemical plant analysis. Plant Soil. 24, 63-80.

Paparnakis, A., Chatzissavvdid, C., Antoniadis, V. 2013. How apple responds to boron excess in acidic and limed soil. J. Soil Sci. Pl. Nutr. 7, 787796.

Pinho, L.G.R., Monnerat, P.H., Pires, A.A., Santos, A.L.A. 2008. Boron Absorption and Redistribution in Green Dwarf Coconut Tree. Pesquisa Agropecuária Brasileira. 43, 1769-1775.

Prabowo, N.E., Tohiruddin, L.Tandiono, J., Foster, H.L. 2010. Identification and evaluation of problem fields: an implementation of a yield prediction tool based on palm data. International Oil Palm Conference, Yogyakarta, Indonesia.

Prado, R.M. 2008. Plant Nutrition. (Sao Paulo:) Editora.UNESP.p 407.

Reuter, D.J., Robinson, J.B. 1986. Plant analysis an interpretive manual. Inkata Press, Melbourne, Australia.

Sharma, U.C. 1991. A simple mathematical model to determine critical nutrient levels in soil and plant. J. Indian Soc.Soil Sci. 39, 509-513.

Singh, S.S. 2009. Soil fertility and nutrient management. Kalyani Publishers, Ludhiana., pp. 136-140. 
Ware, G.O., Ohki, K., Moon, L.C. 1982. The Mitschelich plant growth model; for determining critical nutrient deficiency levels. Agron. J. 74, 88-91.

Wójcik, P., Mika, A. 1998. Effect of removal of spur leaves on apple fruit quality. Agric. Sci. Ann. 113, 65-76.
Wasaya, A., Shabir, M.S., Hussain, M., Ansar, M., Aziz, A., Hassan,W., Ahmad, I. 2017. Foliar application of zinc and boron improved the productivity and net returns of maize grown under rainfed conditions of Pothwar plateau. J. Soil Sci. Plant. Nutr. 17, 33-45 